\title{
PENURUNAN BEBAN PENCEMAR PADA LIMBAH DOMESTIK DENGAN MENGGUNAKAN MOVING BED BIOFILTER REAKTOR (MBBR)
}

\author{
Muhammad Al Kholif 1), Joko Sutrisno 2) dan Ilham Dwi Prasetyo ${ }^{3)}$ \\ 1) Program Studi Teknik Lingkungan, Fakultas Teknik Sipil dan Perencanaan, \\ Universitas PGRI Adi Buana (UNIPA) Surabaya - Indonesia \\ alkholif87@unipasby.ac.id \\ 2) Program Studi Teknik Lingkungan, Fakultas Teknik Sipil dan Perencanaan, \\ Universitas PGRI Adi Buana (UNIPA) Surabaya - Indonesia \\ Isutrisno.adibuana@yahoo.com \\ 3) Program Studi Teknik Lingkungan, Fakultas Teknik Sipil dan Perencanaan, \\ Universitas PGRI Adi Buana (UNIPA) Surabaya - Indonesia \\ ilhamdwi@yahoo.com
}

\begin{abstract}
Greywater generally contains pollutants such as Biological Oxigen Demand (BOD), Chemical Oxigen Demand (COD), Total Suspended Solid (TSS), and mixed particles. This pollutant substance usually exceeds the standard of greywater quality based on East Java Governor regulation number 52 year 2014. The technology applied in this research is Moving Bed Biological Reactor (MBBR) technology. The objective is to assess the ability of MBBR to make kaldness on the reduction of pollutant load on greywater. Greywater used as research sample is sourced from Gembong RW 5 Surabaya area. The study was conducted for 7 days to find out how much the efficiency of MBBR in reducing the pollutant load. Acclimatization period lasts for 18 days to reach steady state condition. The data obtained were analyzed by graph method. This is done to facilitate the reading of the results of the analysis. The analyzed waste parameters are $\mathrm{BOD}_{5}$, COD and TSS. The results of initial observation of greywater before the treatment was at BOD level of $186.24 \mathrm{mg} / \mathrm{L}$, COD level of 352 $\mathrm{mg} / \mathrm{L}$ and TSS level of $400 \mathrm{mg} / \mathrm{L}$. From the observation results, the efficiency of BOD 5 was $83.3 \%$, COD efficiency was $84.2 \%$ and the efficiency of TSS was $90 \%$.
\end{abstract}

Keywords: $\mathrm{BOD}_{5}$, COD, TSS, Greywater, Moving Bed Biological Reactor

\begin{abstract}
Abstrak
Air limbah domestik umumnya mengandung zat pencemar seperti Biological Oxigen Demand (BOD), Chemical Oxigen Demand (COD), Total Suspended Solid (TSS), dan partikel tercampur. Zat pencemar ini biasanya melebihi standar baku mutu.air limbah domestik berdasarkan peraturan Gubernur Jawa Timur nomor 52 tahun 2014. Teknologi yang diterapkan dalam penelitian ini adalah teknologi Moving Bed Biological Reactor (MBBR). Tujuannya yaitu mengkaji kemampuan MBBR bermedia kaldness terhadap penurunan beban pencemar pada limbah cair domestik. Air limbah domestik yang dijadikan sebagai sampel penelitian bersumber dari daerah Gembong RW 5 Surabaya. Penelitian dilakukan selama 7 hari untuk mengetahui seberapa besar efisiensi MBBR dalam menurunkan beban pencemar tersebut. Masa aklimatisasi berlangsung selama 18 hari untuk mencapai kondisi steady state. Data yang diperoleh dianalisis dengan metode grafik. Hal ini dilakukan untuk memudahkan dalam pembacaan hasil analisis. Parameter limbah yang dianalsisi yaitu $\mathrm{BOD}_{5}$, COD dan TSS. Hasil pengamatan awal limbah cair domestik sebelum terolah adalah pada kadar BOD sebesar186,24 mg/L, kadar COD sebesar $352 \mathrm{mg} / \mathrm{L}$ dan kadar TSS sebesar $400 \mathrm{mg} / \mathrm{L}$. Dari hasil pengamatan dilapangan diperoleh efisiensi penyisishan BOD5 adalah 83,3\%, efisiensi COD sebesar 84,2\% dan efisiensi penyisishan TSS sebesar $90 \%$.

Kata Kunci: BOD $_{5}$, COD, TSS, Limbah Cair Domestik, Moving Bed Biological Reactor
\end{abstract}




\section{PENDAHULUAN}

Limbah cair domestik atau limbah cair rumah tangga menjadi ancaman serius karena limbah tersebut dipastikan mencemari lingkungan, khususnya air tanah yang dapat berfungsi juga sebagai media pembawa bibit penyakit. Limbah domestik rumah tangga yang dihasilkan umumnya dari sisa-sisa buangan kamar mandi, kotoran manusia, dan dapur. Limbah merupakan buangan atau sesuatu untuk dihilangkan dan bersifat berbahaya. Bahan kimia tersebut dapat memberi kehidupan bagi kumankuman penyebab penyakit, seperti disentri, typus, dan penyakit lainnya (Doddy,2012).

Tujuan dari pengolahan limbah domestik adalah untuk mengurangi kadar pencemaran Biological Oxigen Demand (BOD), Chemical Oxigen Demand (COD), Total Suspended Solid (TSS), dan partikel tercampur, serta untuk menghilangkan bahan nutrisi dan komponen beracun yang tidak dapat didegradasikan konsentrasi yang ada menjadi rendah. Metode dasar penanganan limbah domestik terdiri dari tahap pengolahan dasar, pengolahan kedua, dan penanganan tersier (Sami M, 2012). Pengolahan dasar meliputi pembersihan grit, penyaringan, penggilingan, dan sedimentasi. Masalah pencemaran lingkungan oleh air limbah saat ini sudah sampai pada tahap yang mengkhawatirkan seperti halnya di kota Surabaya. Perubahan karakteristik limbah rumah tangga tergantung pada jenis dan jumlah asupan makanan dan air yang bercampur dengan limbah (Agbogu et al, 2005).

Kehadiran limbah dapat berdampak negatif terhadap lingkungan dan terutama bagi kesehatan manusia, sehingga perlu dilakukan pengolahan terhadap limbah. Tingkat bahaya keracunan yang ditimbulkan oleh limbah tergantung pada jenis dan karakteristik limbah (Soeparman dan Soeparmin, 2002). Biofilm merupakan salah satu pengolahan limbah cair secara biologis, dimana proses kerjanya memanfaatkan kehidupan mikroorganisme untuk menguraikan polutan. Adapun beberapa keunggulan dari biofilm antara lain pengoperasiannya yang cukup mudah, lumpur yang dihasilkan sedikit, tahan terhadap fluktuasi jumlah air limbah maupun fluktuasi konsentrasi, serta dapat menghilangkan padatan tersuspensi dengan baik. Teknologi biofilter mampu menghapus kandungan bahan organik sampai tingkat efisiensi 95\% (Ratnawati R 2013).

Air limbah domestik adalah air buangan manusia yang berasal dari perumahan, daerah komersial, institusi dan fasilitas sejenis (Metcalf dan Eddy,1991). Limbah cair domestik adalah semua jenis bahan sisa yang dibuang di dalam bentuk larutan atau zat cair. Limbah cair dapat berupa air bekas cucian, busa detergent, dan lain-lain. Menurut Keputusan Gubernur Jawa Timur Nomor 52 Tahun 2014. Air limbah domestic yang akan diolah merupakan air limbah domestik di daerag Gembong RW 5 Surabaya. Air limbah domestik ini akan diolah dengan alat Moving Bed Biofilter Reaktor (MBBR) bermedia kaldness dan batu apung. MBBR adalah suatu metode pengolahan limbah dengan menggunakan media bergerak. Alat ini umumnya digunakan untuk penjernihan kolam ikan atau aquarium. Metode $M B B R$ ini memiliki kemampuan untuk mereduksi beban pencemar BOD hingga $20 \mathrm{mg} / \mathrm{L}$ (Achmad Setiyawan, 2014).

Kondisi awal limbah cair domestik untuk parameter $\mathrm{BOD}_{5}, \mathrm{COD}$, dan TSS masih di atas baku mutu limbah cair domestik rumah tangga yang ditetapkan oleh Peratutan Gubenur Jawa Timur No 52 Tahun 2014, data awal sebelum melakukan pengolah untuk kadar BOD 186,24 mg/l, COD 352 mg/l, TSS $400 \mathrm{mg} / \mathrm{l}$, sedangkan Peraturan Gubenur Jawa Timur No 52 Tahun 2014 mensyaratkan untuk kadar BOD $75 \mathrm{mg} / \mathrm{l}$, COD $180 \mathrm{mg} / \mathrm{l}$, dan TSS $60 \mathrm{mg} / \mathrm{l}$. penelitian ini menggunakan variasi media batu apung dan kaldness untuk melihat seberapa besar penurunan kadar BOD, COD, dan TSS pada limbah cair domestic setelah diolah dengan sistem MBBR. 


\section{METODE PENELITIAN}

Muthukumaran et al. (2011) menyatakan bahwa penggunaan air limbah domestik untuk menyiram toilet dan irigasi dapat mengurangi konsumsi air setidaknya 50\%. Air limbah domestik akan sangat bermanfaat jika dapat diolah menjadi air bersih. Dengan teknologi pengolahan yang tepat air limbah domestik yang diolah akan memiliki nilai guna kembali dan tidak harus dibuang sebagai limbah yang mungkin dapat menyebabkan pencemaran lingkungan di kemudian hari. Teknologi yang digunakan untuk mengolah air limbah domestik diantaranya adalah pengolahan secara kimia, fisika dan biologi. Teknik utama pengolahan secara kimia diterapkan untuk mengolah air limbah domestik sperti koagulasi, pertukaran ion dan karbon aktif (Li F et al., 2009). Pidou et al. (2008) melakukan studi yang menggunakan koagulasi dan resin pertukaran ion magnetik.

Sampel yang digunakan dalam penelitian ini adalah limbah cair domestik di daerag Gembong RW 5 Surabaya. Pengamatan beban pencemar $\mathrm{BOD}_{5}, \mathrm{COD}$ dan TSS dilakukan setelah air limbah domestik terjadi pada kondisi stady state, dimana untuk mencapai kondisi stady state dibutuhkan waktu selama 18 hari.

Reaktor MBBR dirancang dalam skala laboratorium dengan dimensi seperti pada tabel 1. Reactor MBBR terbuat dari bahan akrilik dengan ketebalan $5 \mathrm{~mm}$. Pada bagian atas reaktor MBBR di biarkan tanpa ada penutup, di bagian samping kanan dan kiri di beri lubang dengan ukuran pipa pvc $3 / 4$ inchi sebagai inlet dan outlet, di bagian depan reaktor diberi kran ukuran $3 / 4$ inchi untuk pengambilan sampel. Adapun gambar rekator MBBR untuk mengolah limbah domestik secara lengkap dapat dilihat pada Gambar 1.

Pengumpulan data dilakukan dengan menggunakan observasi antara lain: sampel limbah awal, meliputi parameter $\mathrm{BOD}_{5}, \mathrm{COD}$, dan TSS. Prosedur pengoperasian reaktor MBBR adalah sebagai berikut: mengatur influen air limbah yang masuk ke dalam reaktor dengan menggunakan valve sesuai debit sebesar $0,086 \mathrm{~m}^{3} /$ hari, media yang digunakan pada penelitian ini batu apung dan kaldness. Proses aklimatisasi berlangsung selama 18 hari untuk mencapai kondisi steady state. Effluent dari MBBR diambil dan di analisis sesuai dengan parameter yang diukur secara berkala, pengukuran parameter $\mathrm{BOD}_{5}, \mathrm{COD}$, dan TSS dilakukan sebelum dan sesudah pengolahan. Proses pengambilan data dilakukan selama 7 hari. Data yang terkumpul berasal dari hasil ovservasi dokumentasi dan experiment pemeriksaan laboratorium akan di pilah sesuai dengan bagiannya untuk mendapatkan kesimpulan (APHA, 2005). Metode analisa data yang dipergunakan metode kuantitatif yakni berupa penyajian data dalam bentuk grafik.

Tabel 1. Dimensi Reaktor Moving Bed Filter

\begin{tabular}{clcccc}
\hline No & Reaktor & $\begin{array}{c}\text { Panjang } \\
\text { (m) }\end{array}$ & $\begin{array}{c}\text { Lebar } \\
\text { (m) }\end{array}$ & $\begin{array}{c}\text { Tinggi } \\
\text { (m) }\end{array}$ & $\mathbf{V ( m )}$ \\
\hline 1 & Bak & 0,30 & 0,30 & 0,50 & 0,075 \\
& $\begin{array}{l}\text { moving } \\
\text { bed } \\
\text { filter }\end{array}$ & & & & \\
\hline 2 & Media & 0,30 & 0,30 & 0,15 & 0,013 \\
& $(30 \%)$ & & & & \\
\hline 3 & $\begin{array}{l}\text { Tinggi } \\
\text { ruang } \\
\text { bebas }\end{array}$ & & & 0,10 & \\
\hline 4 & $\begin{array}{l}\text { Tinggi } \\
\text { air } \\
\text { diatas } \\
\text { media }\end{array}$ & & & & \\
\hline
\end{tabular}

Sumber : Data Primer, 2017

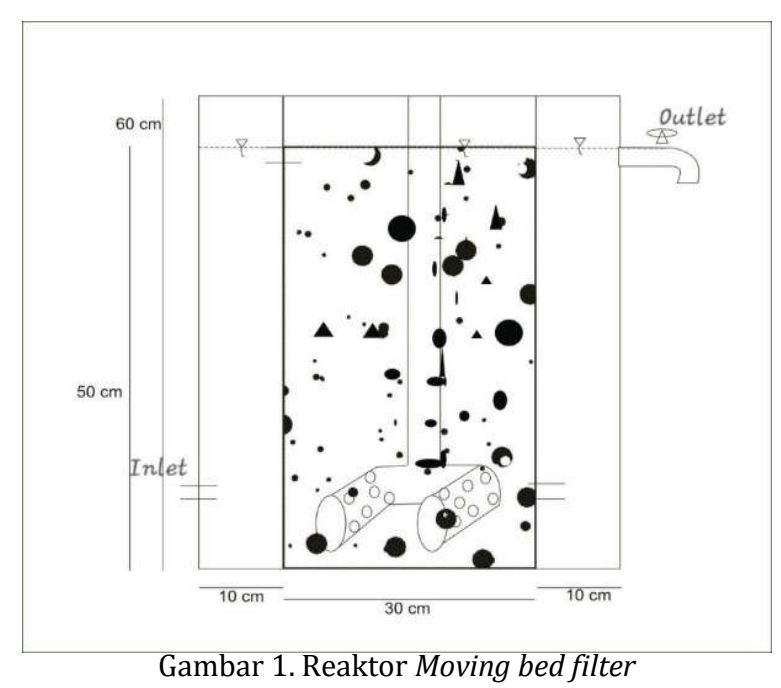




\section{HASIL DAN PEMBAHASAN}

Dari seluruh rangkaian percobaan yang telah dilakukan diperoleh hasil penelitian yang kemudian dikelompokkan dan dianalisa sehingga diperoleh hasil dan pembahasan. Karakteristik awal limbah domestik memiliki beberapa tahapan, yaitu tahapan aklimatisasi, kinerja MBBR dalam menurunkan beban pencemar $\mathrm{BOD}_{5}, \mathrm{COD}$, TSS pada air limbah domestik.

\section{Karakteristik Awal Limbah Cair Domestik}

Dari hasil percobaan awal diperoleh karakteristik limbah cair domestik di Gembong RW 5 Surabaya yang digunakan dalam percobaan ini dapat dilihat pada tabel 2.

Tabel 2. Karakteristik Limbah Cair Domestik di Gembong VI Surabaya

\begin{tabular}{ccccc}
\hline No & $\begin{array}{c}\text { Parameter } \\
\text { Pemeriksaan }\end{array}$ & Satuan & $\begin{array}{c}\text { Batas } \\
\text { Maximum }\end{array}$ & Hasil \\
\hline $\mathbf{1}$ & BOD & $\mathrm{mg} / \mathrm{L}$ & 75 & 186,24 \\
\hline $\mathbf{2}$ & COD & $\mathrm{mg} / \mathrm{L}$ & 180 & 352 \\
\hline $\mathbf{3}$ & DO & $\mathrm{mg} / \mathrm{L}$ & - & 1,2 \\
\hline $\mathbf{4}$ & TSS & $\mathrm{mg} / \mathrm{L}$ & 60 & 400 \\
\hline Sumber: Data Primer, 2017 & &
\end{tabular}

Pada tabel 2 dapat dipaparkan bahwa karakteristik awal limbah cair domestik di Gembong 5 Surabaya masih di atas baku mutu yang telah ditetapkan berdasarkan Pergub Jatim no 52 tahun 2014. Terlihat pada parameter BOD hasil analisis mencapai $186,24 \mathrm{mg} / \mathrm{l}$, COD $352 \mathrm{mg} / \mathrm{l}$ dan TSS 400 $\mathrm{mg} / \mathrm{l}$. Pada ketiga parameter tersebut terlihat nilai konsentrasinya sangat tinggi dibandingkan dengan nilai standar baku mutunya. Sehingga dalam percobaan ini digunakan alat yaitu MBBR untuk menurunkan konsentrasi BOD, COD, dan TSS agar memenuhi baku mutu air buangan.

\section{Efisiensi Penurunan BOD $_{5}$}

Pengaruh media terhadap efisiensi penurunan beban pencemar $\mathrm{BOD}_{5}$ dapat diketahui setelah reaktor MBBR beroperasi. Dari hasil analisis di laboratorium efisiensi penurunan BOD selama tujuh hari reaktor beroperasi dengan tujuh kali pengamatan setiap hari menunjukan ada efisiensi penurunannya. Efisiensi penurunan $\mathrm{BOD}_{5}$ pada limbah cair domestik setelah dilakukan pengoperasian dengan MBBR mengalami penurunan cukup segnifikan dan telah memenuhi baku mutu pada reaktor terutama pada media kaldness. Hasil penurunan $\mathrm{BOD}_{5}$ pada limbah domestik di dalam reaktor MBBR dapat dijelaskan pada gambar 2 berikut.

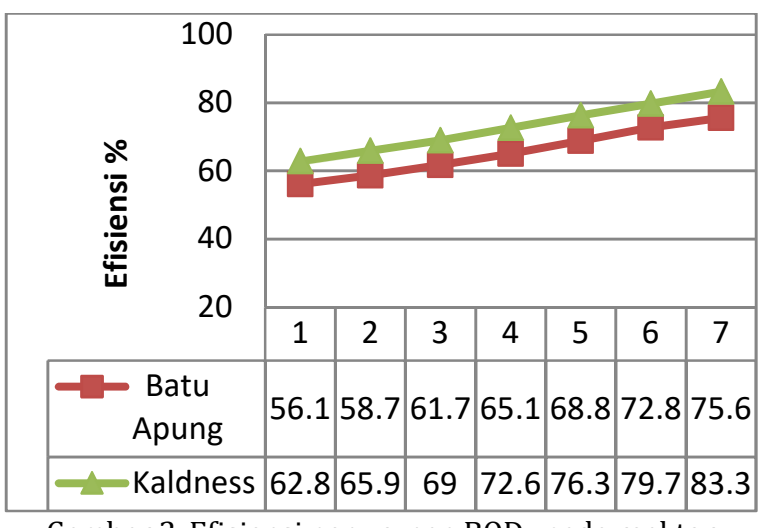

Gambar 2. Efisiensi penurunan $\mathrm{BOD}_{5}$ pada reaktor MBBR

Gambar 2. Terlihat bahwa pengolahan di hari ke satu sampai dengan hari ke tujuh mengalami peningkatan efisiensi penurunan $\mathrm{BOD}_{5}$, terlihat peningkatan efisiensi tertinggi pada hari ke tujuh pada media Kaldness sehingga penurunan $\mathrm{BOD}_{5}$ yang paling efektif adalah media kaldness 83,3\%, dan media Batu apung 75,6\%. Tingginya nilai efisiensi penurunan kadar BOD5 pada media kaldness dikarenakan media Kaldness memiliki pori yang cukup banyak sehingga mikroorganisme pengurai limbah banyak yang menempel dan ditunjangi waktu tinggal selama satu hari. Menurut Apriani Isna, dkk (2003), pada penelitian, melakukan pengolahan dengan menggunakan reaktor biofilter dapat menurunkan pencemaran $\mathrm{BOD}_{5}$ dari 785,5 $\mathrm{mg} / \mathrm{l}$ menjadi 435,29 mg/l dengan efisiensi 44,5\%. Dengan kesimpulan dalam penurunan konsentrasi pencemaran $\mathrm{BOD}_{5}$ limbah cair domestik lebih efektif menggunakan media kaldness dengan perlakuan MBBR. Efisiensi removal $\mathrm{BOD}_{5}$ berkisar antara 78-98\% 
tergantung dari sumber air limbah domestik (A. Asseyed et al., 2014).

\section{Efisiensi Penurunan COD}

Sama halnya dengan penyisihan pencemar $\mathrm{BOD}_{5}$, pada parameter $\mathrm{COD}$ juga menagalami penyisihan dalam pengolahannya. Dalam beberapa kasus yang terjadi, banyak bentuk pengolahan limbah cair domestik yang diolah untuk menjadi air bersih sehingga dapat dimanfaatkan kembali untuk kebutuhan lain. Penggunaan kembali air olahan limbah cair domestik dapat memberikan perubahan yang signifikan, baik dalam segi ekonomi maupun dalam aspek lingkungan, terutama pemakaian air bersih. Penggunaan kembali air olahan limbah cair domestik memberikan dampak positif dengan berkurangnya pengeluaran untuk kebutuhan air minum dan biaya keperluan lain (E. de Aguiar do Couto et al, 2015). Efisiensi penyisihan pencemar COD ditunjukan pada gambar 3. Dari pengolahan yang telah dilakukan dapat dikatakan bahwa angka penurunan Pencemar $\mathrm{BOD}_{5}$ dan COD mengalami penurunan yang signifiakan, yaitu rata-rata $67 \%$ untuk angka efisiensi $\mathrm{BOD}_{5}$ dan $68 \%$ pada angka efisiensi COD. Sama halnya dengan penelitian yang dilakukan oleh E. de Aguiar do Couto et al (2015) dan HernandezLeal et al, (2011), dimana rata-rata efisiensi penurunan angka COD mencapai 64\% pada reaktor UASB dan 70\% pada reaktor anaerob.

Efisiensi penurunan COD pada limbah cair domestik setelah dilakukan pengoperasian dengan $M B B R$ mengalami penurunan cukup segnifikan yaitu pencapaian $84,2 \%$ dan telah memenuhi baku mutu yang telah ditentukan. Hasil penurunan COD pada limbah domestik di dalam reaktor MBBR dapat dijelaskan pada gambar 3 berikut.

Dari gambar 3. Terlihat bahwa pengolahan di hari ke satu sampai dengan hari ke tujuh mengalami peningkatan efisiensi penurunan COD, terlihat peningkatan efisiensi tertinggi pada hari ke tujuh pada media Kaldness sehingga penurunan COD yang paling efektif adalah media Kaldness 84,2\%, dan media Batu apung 70,8\%, Pada penelitian (Rahmiyati
F,2008), menyatakan bahwa penurunan konsentrasi pada limbah cair domestik dengan menggunakan reaktor biofilter anaerobik media arang tempurung kelapa efesiensinya $62,22 \%$, sedangkan media krikil $44,22 \%$, hal itu menunjukkan bahwa penurunan beban pencemar COD lebih efektif menggunakan pengolahan MBBR dengan media batu apung dan kaldness.

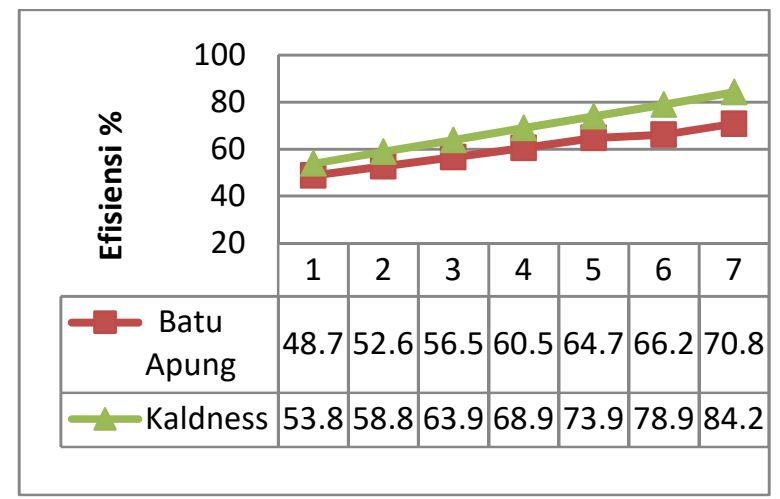

Gambar 3. Efisiensi penurunan COD pada reaktor MBBR

Penerapan pasir silika sebagai media filter dalam pengolahan limbah domestik yang diterapkan beberapa batch mampu menyisihkan pencemar COD hingga 90\% (Kang et al., 2007). Dengan system pengolahan yang murah dan mudah, maka pengolahan air limbah domestik untuk digunakan kembali dapat berkontribusi dalam pengembangan lingkungan maupun wilayah perkotaan (E. de Aguiar do Couto et al 2015). Penggunaan satu teknologi tidak akan cukup untuk memenuhi standar penggunaan kembali hasil olahan limbah cair domestik. Dengan dmikian perlu adanya penggabungan teknologi untuk memungkinkan penggunaan kembali air limbah domestik sesuai dengan baku mutu yang ditentukan (Ghaitidak dan Yadav, 2013).

\section{Efisiensi Penurunan TSS}

Efisensi penurunan TSS pada limbah cair domestik untuk setiap reaktor media Batu apung dan kaldness dapat diketahui setelah reaktor media Moving bed filter beroperasi. Dari hasil pengamatan selama tujuh hari didapat efisiensi penurunan kosentrasi TSS setelah dilakukan analisa Laboratorium 
untuk mengetahui berapa persentasi penurunan yang dihasilkan oleh MBBR.Terlihat efisiensi penurunan TSS Selama tujuh hari beroperasi dengan waktu pengamatan setiap hari. Efisiensi penurunan limbah domestik setelah dilakukan perlakuan dengan reaktor MBBR mengalami penurunan cukup signifikan mencapai $90 \%$ pada hari ke delapan belas dengan media Kaldness dan telah memenuhi baku mutu. Hasil penurunan TSS pada limbah domestik dalam reaktor MBBR dijelaskan pada gambar 4 berikut.

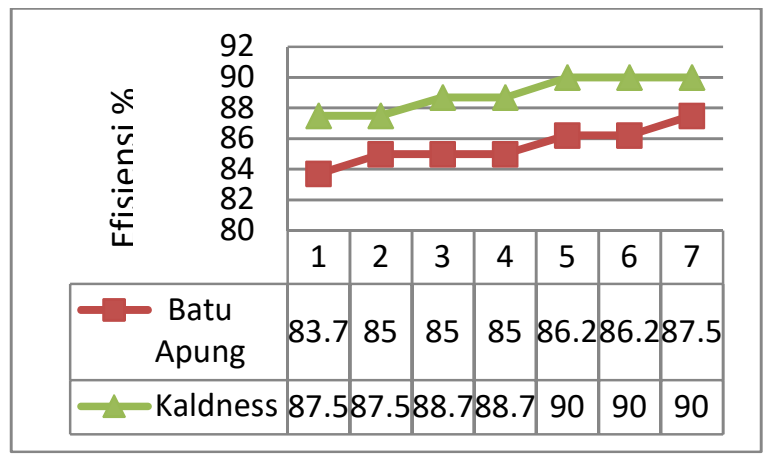

Gambar 4. Hasil penurunan kadar TSS

Proses penurunan terhadap TSS ini terjadi karena adanya proses pengendapan dan resirkulasi sehingga dapat membantu menurunkan konsentrasi TSS dan juga dipengaruhi oleh waktu tinggal air limbah dikarenakan semakin lama air limbah tinggal di dalam reaktor semakin banyak padatan tersuspensi yang terserap oleh lapisan biofilm sehingga efisiensi penurunan TSS semakin tinggi. Hal ini sesuai dengan pendapat Said (2002), bahwa semakin lama waktu kontak antara air limbah dengan media maka effluen yang dihasilkan akan lebih kecil dan efisiensi penurunan menjadi tinggi.

Dari hasil perbandingan reaktor media batu apung dan kaldness dalam menurunkan konsentrasi $\mathrm{BOD}_{5}, \mathrm{COD}$, dan TSS pada limbah cair domestik. Bahwa reaktor media Kaldness dapat menurunkan konsentrasi BOD, COD, dan TSS lebih efektif dibandingkan reaktor media Batu apung. Media kaldness memiliki pori-pori yang cukup banyak sehingga dapat menampung lebih banyak mikroorganisme pengurai sebab memiliki diameter dan luas permukaan yang lebih kecil. Luas permukaan dapat dilihat dari nilai porositas media tersebut, semakin kecil nilai porositas media maka luas permukaannya semakin besar. Media Kaldness memiliki porositas lebih kecil daripada media batu apung yakni pada media kaldness 56\% dan batu apung 74\%. Luas permukaaan besar dan porositas rongga yang ada memungkinkan melekatnya mikroorganisme yang banyak pula (Halvard Odergard, 2015).

\section{KESIMPULAN}

Setelah dilakukan penelitian didapatkan hasil bahwa metode ini efektif untuk menurunkan beban pencemar $\mathrm{BOD}_{5}, \mathrm{COD}$, dan TSS pada limbah cair domestik. Efisiensi tertinggi yang terjadi pada media kaldness untuk parameter $\mathrm{BOD}_{5}$ mencapai $83,3 \%$, kadar COD sebesar $84,2 \%$ dan pada parameter TSS mencapai 90\%. Sedangkan efisiensi tertinggi yang terjadi pada media batu apaung untuk parameter $\mathrm{BOD}_{5}$ mencapai $75,6 \%$, pada parameter COD mencapai 70,8\% dan TSS mencapai 87,5\%. Secara keseluruhan penggunaan media kaldness dan batu apung sangat efektif untuk diterapkan dalam pengolahan limbah terutama limbah domestik.

\section{DAFTAR PUSTAKA}

Agbogu, V. N.; Umoh, V. J.; Okuofu, C. A.; Smith, S. I. and Ameh, J. B. (2005): Study of the Bacteriological and Physiochemical Indicators of Pollution of Surface waters in Zaria; Nigeriall African Journal of Biotechnology, Vol. 5, No. 9, pp. 732-737. Ahmad S. Setiyawan, Toshiro Yamada, Joni A. Fajri, Fusheng Li (2014). Sekolah Pascasarjana Teknik, Universitas Gifu, Jepang 2) Jurusan Teknik Lingkungan, Institut Teknologi Bandung, Indonesia 3) Jurusan Teknik Sipil, Universitas Gifu, Jepang 4) Pusat Penelitian Lembah Sungai, Universitas Gifu, Jepang. Journal of Water and Environment Technology. vol 12(2014) No.6 pp.469-480.

Al-Hamaiedeh, H., Bino, M., 2010. Effect of treated greywater reuse in irrigation on 
soil and plants. Desalination 256, 115119.

APHA, 2005. Standard Methods for the Examination of Water and Wastewater, $21^{\text {st }}$ ed. American Public Health Association, American Water Works Association Water Environmental Federation, Washington.

Apriani Isna, Mega Filliazat dan Titin Anita Zahara. (2003). Pengolahan Limbah Cair Domestik Dengan Biofilter Aerob Menggunakan Media Bioball dan Tanaman Kiambang. / Program Studi Teknik Lingkungan, Fakultas Teknik, Universitas Tanjungpura, PontianakProgram Studi Kimia, Fakultas MIPA, Universitas Tanjungpura, Pontianak.

Asri, (2006). Penurunan BOD dan COD pada Limbah Domestik Limbah Tahu Dengan Media Karbon Aktif Tempurung Kelapa. Laporan Tugas Akhir Teknik Lingkungan FTSP-ITS, Surabaya.

Assayed, A., Chenoweth, J., Pedley, S., 2014. Drawer Compacted Sand Filter: a new and innovative method for on-site greywater treatment. Environ. Technol. 35, 2435-3446.

Azimah N, (2015). Penurunan Kadar BOD dan COD Pada Limbah Domestik Dengan Menggunakan Biofilter Anaerobik / Skripsi Tahun 2015.

Dalahmeh, S., Assayed, M., Suleiman, W., 2009. Themes of stakeholder participation in greywater management in rural communities in Jordan. Desalination 243, 159-169.

Dalahmeh, S., Pell, M., Vinneras, B., Hylander, L., Oborn, I., Jonsson, H., 2012. Efficiency of bark, activated charcoal, foam and sand filters in reducing pollutants from greywater. Water Air Soil Pollut. 7, 3657-3671.

Doddy Octniawan, (2012) Pengolahan Limbah Cair Domestik Dengan Menggunakan Rotary Biological Contractor (RBC). Laporan Tugas Akhir Teknik Lingkungan FTSP-Veteran. Surabaya.

Eduardo de Aguiar do Couto, Maria Lúcia Calijuri, Paula Peixoto Assemany, Aníbal da Fonseca Santiago, Lucas Sampaio
Lopes, 2015. Greywater treatment in airports using anaerobic filter followed by UV disinfection: an efficient and low cost alternative. Journal of Cleaner Production 106, 372-379.

Ganjar Samudro, Fauzia Rahmiyati Yazid, dan Syafrudin, (2008). Pengaruh Variasi Konsentrasi dan Debit Pada Pengolahan Air Artifisial (Campuran Grey Water dan Black Water) Menggunakan Reaktor UASB/Program Studi Teknik Lingkungan Fakultas Teknik UNDIP/Vol. 9 No.1 Maret 2012, ISSN 1907-187X.

Ghaitidak, D.M., Yadav, K.D., 2013. Characteristics and Treatment of Greywater e a Review. Environ. Sci. Pollut. Res. 0, 2795-2809.

Halvard Odergard, (2015). Pengolahan Air dengan Sistem Filtering Biologis dengan Media Kaldness.

Idaman Said N, Herlambang (2002). Teknologi Pengolahan Limbah Air Limbah $B B P T$, Jakarta.

Kang, Y., Mancl, K., Tuovinen, O., 2007. Treatment of turkey processing wastewater with sand filtration. Bioresour.Technol. 98, 1460-1466.

Li, F., Wichmann, K., Otterpohl, R., 2009. Review of the technological approaches for grey water treatment and reuses. Sci. Total Environ. 407, 3439-3449.

Metcalf \& Eddy, (2004), Wastewater Engineering Treatment and Reuse, Fourth Edition, McGraw-Hill Inc. New York.

Muthukumaran, S., Baskaran, K., Sexton, N., 2011. Quantification of potable water savings by residential water conservation and reuse. Resour. Conserv. Recycl. 55, 945-952.

Peraturan Gubenur Jawa Timur, Baku Mutu Air Limbah Domestik NO 52 tahun 2014. Surabaya.

Pidou, M., Avery, L., Stenphenson, T., Jeffrey, P., Parsons, S.A., Liu, S., Memon, F.A., Jefferson, B., 2008. Chemical solutions for greywater recycling. Chemosphere 71, 147-155.

Prasetyo E, (2015). Penurunan Kadar COD, TSS Dan Minyak Lemak Pada Limbah Cair Pencucian Kendaraan Bermotor 
Menggunakan Biofilter Aerobik / Skripsi Tahun 2015.

Ratnawati R, M Al Kholif dan Sugito, (2013), Desain Instalasi Pengolahan Air Limbah (IPAL) Biofilter Untuk Mengolah Air Limbah Poliklinik Unipa Surabaya /Jurnal Teknik Waktu Volume 12 Nomer 02 - Juli 2014 - ISSN :1412 - 1867.

Sami M (2012). Penyisihan COD TSS dan $p H$ Dalam Limbah Cair Domestik Dengan Metode Fixed-bed Column Up-flow Jurusan Teknik Kimia Politeknik Negeri Lhoksumawe/ Vol 10 No 21- Juni- 2012 ISSN1693-248.

Soeparman, Soeparmin, (2002). Pembuangan Tinja dan Limbah Cair. Penerbit EGC: Jakarta. 